mgr lic. Alicja Czernia

Sąd Diecezjalny w Tarnowie

\title{
Notariusz w procesach Sądu Diecezjalnego w Tarnowie w latach 1983-2015
}

Notariusz w sądzie kościelnym jest tym urzędem, który istniał od początku samej instytucji, mimo zmieniających się przepisów. Chociaż notariusz pełni funkcję podrzędną wobec sędziego, jego obecność była zawsze wymagana. Zakres zadań notariusza podlegał pewnym niewielkim zmianom, ale zasadnicza jego rola, uwierzytelnianie i piecza nad aktami procesu pozostała niezmienna.

W niniejszym opracowaniu postaram się omówić rolę notariusza w Sądzie Diecezjalnym w Tarnowie w latach 1983-2015. Jest to okres wyznaczony przez dwa akty prawne Kościoła katolickiego: Kodeks prawa kanonicznego z $1983 \mathrm{roku}^{1}$ i list apostolski motu proprio Mitis Iudex

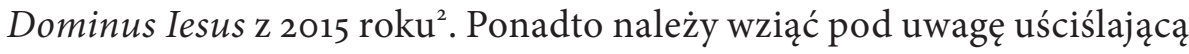

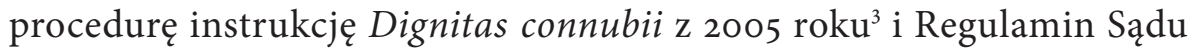
Diecezjalnego w Tarnowie z 2015 roku $^{4}$. Zmiany w prawie procesowym wprowadzone przez wymienione akty powodowały zmiany w funkcjonowaniu notariatu, choć wypada zaznaczyć, iż były to zaledwie niewielkie korekty, współgrające z wieloletnią praktyką sądu.

\footnotetext{
1 Kodeks prawa kanonicznego [dalej: KPK] ogłoszony przez Jana Pawła II 25 stycznia 1983 roku (wszedł w życie 27 listopada 1983 roku).

2 Dokument ogłoszony przez papieża Franciszka 8 września 2015 roku (obowiązujący od 8 grudnia 2015 roku).

3 Instrukcja Dignitas connubi [dalej: DC] ogłoszona 25 stycznia 2005 roku (weszła w życie w dniu publikacji).

4 Regulamin Sądu Diecezjalnego w Tarnowie [dalej: Regulamin] ogłoszony przez biskupa Andrzeja Jeża 1 lutego 2015 roku (wszedł w życie w dniu ogłoszenia).
} 
Alicja Czernia

Ponieważ zagadnienie jest dość obszerne, świadomie dokonane zostało zawężenie tematu do zwyczajnego procesu o stwierdzenie nieważności małżeństwa, gdyż jest to proces najczęściej występujący oraz najpełniej prezentujący zadania notariusza i sposób ich realizacji. Poszczególne zagadnienia przedstawię w kolejnych punktach, odpowiadających etapom procesu. W pierwszym punkcie zostaną przedstawieni ludzie, którzy pełnili funkcję notariusza w Sądzie Diecezjalnym w Tarnowie i w sposób istotny przyczynili się do ustalenia obecnej praktyki.

\section{Notariusze Sądu Diecezjalnego w Tarnowie (1983-2015)}

Mimo iż funkcja notariusza w Sądzie Diecezjalnym w Tarnowie istniała nieprzerwanie od początku funkcjonowania sądu, obecne zasady działania można wyprowadzić z przepisów KPK 1983. W czasie gdy KPK 1983 został ogłoszony, notariuszem sądu był ks. Jan Ptak. Z lektury akt tamtego okresu można wyciągnąć wniosek, że zasady działania notariusza zostały w krótkim czasie dostosowane do wymogów nowego prawa. Redagowane dokumenty odwoływały się wyłącznie do kanonów KPK 1983, a zostały zupełnie oderwane od wskazań instrukcji Kongregacji Sakramentów Provida mater $\mathrm{z} 1936$ roku. Było to niewątpliwie dość odważne rozwiązanie, zważywszy że wiele sądów w Polsce jeszcze przez wiele lat opierało szczegółowe zasady działania właśnie o ten dokument.

Ksiądz mgr Jan Ptak pełnił funkcję do września 1987 roku. Po nim funkcję notariusza objął ks. dr Edward Gabryel. Był to czas rozwijania i krzepnięcia praktyki sądowej opartej o przepisy KPK 1983, określającej szczegółowe zasady działania tam, gdzie kodeks wskazywał na konieczność wprowadzenia partykularnych rozwiązań.

Kolejna zmiana na stanowisku notariusza nastąpiła w wrześniu 1991 roku. Potrzeby sądu sprawiły, że ks. dr Edward Gabryel otrzymał nominację na stanowisko sędziego, natomiast funkcję notariusza objęła po raz pierwszy osoba świecka, kobieta, mgr lic. Alicja Czernia, nadal piastująca to stanowisko, autorka niniejszego przedłożenia. Wydaje się, że ta zmiana została pozytywnie odebrana przez interesantów. Osoba świecka w wielu wypadkach odbierana była jako bliższa „zwykłemu” człowiekowi i lepiej rozumiejąca jego problemy. Tylko w nielicznych przypadkach petenci domagali się kontaktu z księdzem, a wtedy z pomocą przychodzili sędziowie. 
W 1998 roku Sąd Diecezjalny został upoważniony do stałej pomocy prawnej dla diecezji ukraińskich (żytomiersko-kijowskiej i lwowskiej). Równocześnie dało się zauważyć w samej diecezji tarnowskiej wzmożone zainteresowanie prowadzeniem procesów o stwierdzenie nieważności małżeństwa. Efektem tego było wpływanie coraz większej liczby skarg, a co za tym idzie rozpoczynanie coraz większej liczby spraw. Wkrótce okazało się, że jeden notariusz w sądzie nie wystarczy do sprawnego wypełniania funkcji, mimo że sądy powołane w Żytomierzu i we Lwowie do 2003 roku zupełnie przejęły sprawy z terenu Ukrainy.

Rok 2005 zaznaczył się wydaniem DC, która wyjaśniła i uszczegółowiła przepisy procesu o stwierdzenie nieważności małżeństwa zawarte W KPK 1983. Odniosła się też do funkcji notariusza, przy czym dało się zauważyć, że zawarte w DC przepisy zasadniczo pokrywały się z praktyką Sądu Diecezjalnego w Tarnowie. Nieznaczna korekta w działaniu notariatu została wprowadzona w ciągu kilku kolejnych lat.

Efektem DC, który przyniósł pomoc, okazało się powołanie w 2007 roku adwokata stałego i stworzenie Poradni Prawno-Kanonicznej przy Sądzie Diecezjalnym w Tarnowie. Adwokat przejął całkowicie poradnictwo przedprocesowe, zwalniając $z$ tego obowiązku notariusza i sędziów. Fachowo przygotowane skargi nie wymagały poprawek, a reprezentowanie stron przed sądem przyspieszyło prowadzenie procesów. Jednak to nie wystarczyło.

Aby usprawnić funkcjonowanie notariatu, w 2008 roku powołany został drugi notariusz. Funkcję tę objął ks. dr Marek Zaborowski. Rozpoczął się okres, kiedy procesy były przyznawane na zmianę jednemu lub drugiemu z notariuszy. Formuła ta nie do końca zdała egzamin, a wkrótce zupełnie zanikła, ponieważ we wrześniu 2009 roku ks. dr Marek Zaborowski został powołany na stanowisko sędziego, w miejsce zmarłego ks. dra Henryka Kościsza. Notariat ponownie stał się jednostką jednoosobową. Wprawdzie sędziowie starali się samodzielnie redagować dekrety i pisma procesowe, ale ta ich aktywność niejednokrotnie powodowała dodatkowe komplikacje.

Sytuacja uległa diametralnej zmianie we wrześniu 2013 roku, kiedy notariat sądu ponownie został wzmocniony drugim pracownikiem. Na stanowisko notariusza został powołany ks. mgr Grzegorz Salamon (nadal pełni tę funkcję). Tym razem współpraca notariuszy została oparta 
o przepis art. $62 \$ 3 \mathrm{DC}^{5}$. Względy praktyczne przemówiły za tym, aby pod nieobecność jednego z notariuszy akta mógł uwierzytelnić jego zastępca. Po dwóch latach funkcjonowania można $\mathrm{z}$ całą pewnością powiedzieć, że taka formuła się sprawdziła. Mimo dużej liczby nowych spraw notariat działa sprawnie i przestał powodować wstrzymywanie biegu procesów.

W punkcie drugim zawarto bardziej szczegółowe omówienie zadań notariusza wynikających z przepisów prawa i praktyki Sądu Diecezjalnego w Tarnowie.

\section{Zadania notariusza}

Spośród pracowników sądu notariusz jest tym, który w sposób szczególny dba o formalną stronę procesu. KPK 1983 nie regulował wprost zakresu zadań notariusza sądowego. Kan. 1437 \$1 KPK 1983 określał jedynie jego najważniejszą funkcję: „W każdym procesie powinien brać udział notariusz, tak że akta należy uznać za nieważne, jeżeli nie zostały przez niego podpisane”. I dalej w \$2: „Akta sporządzone przez notariuszy są publicznie wiarygodne". Oznacza to, że akta podpisane przez notariusza są pełnym dowodem, dokumentem publicznym, całkowicie wiarygodnym ${ }^{6}$. Inne wymogi odnośnie notariusza i jego zadania były wyprowadzane z kanonów odnoszących się do kanclerza kurii'. Wymienia się tu troskę o sporządzanie i wysyłanie akt, strzeżenie ich $\mathrm{w}$ archiwum sądu ${ }^{8}$ oraz prowadzenie rejestrów sądowych ${ }^{9}$. Pisma sporządzane przez notariusza mają charakter urzędowy, o ile zawierają oznaczenie miejscowości, datę i jego podpis ${ }^{10}$. Notariusz powinien być osobą o nieposzlakowanej opinii i poza wszelkim podejrzeniem, a ponadto powinien być kapłanem w sprawach, w których opinia kapłana może być narażona na niebezpieczeństwo ${ }^{11}$. Nie ma tu wymogu odnośnie do wykształcenia, ale wskazane jest, aby był kanonistą ${ }^{12}$.

Por. także pkt 11 Regulaminu.

6 Por. R. Sztychmiler, Sądownictwo kościelne w stużbie praw człowieka, Olsztyn 200o, s. $69-70$.

KPK 482-485.

8 KPK $482 \$ 1,484$ n. 1.

9 KPK kan. 484 n.3.

${ }^{10}$ KРК kan. 483 \$1; КРК kan. 484 n. 2.

${ }^{11}$ KPK kan. $483 \$ 2$.

${ }_{12}$ Por. R. Sztychmiler, Sądownictwo kościelne w stużbie praw człowieka, dz. cyt. s. 70. 
Jak już wyżej wspomniano, w latach 1983-1991 funkcję notariusza w Sądzie Diecezjalnym w Tarnowie pełnili kapłani. W 1991 roku funkcję tę powierzono osobie świeckiej, równocześnie ograniczając zakres jej uprawnień do procesów dotyczących małżeństw. W sprawach dotyczących kapłanów notariuszem ustanawiany był ad casum jeden z sędziów, a w latach 2008-2009 i obecnie (od 2013 roku) funkcję tę pełni ksiądz notariusz.

Zakres zadań w procesie o nieważność małżeństwa został usystematyzowany, uzupełniony i odniesiony wprost do notariusza sądu dopiero W DC (art. 61-62).

Art. $61 \$ 1 \mathrm{DC}^{13}$ określił, że kierownik kancelarii sądu jest równocześnie notariuszem akt sądowych. Jego zadaniem jest należyta troska o to, aby akta sądowe były poprawnie sporządzane, wysyłane i strzeżone $\mathrm{w}$ archiwum.

$\mathrm{Z} \$ 2$ tego artykułu można wyprowadzić szczegółowy katalog czynności należących do notariusza:

- zapisywanie wszystkich akt napływających do sądu;

- odnotowywanie w protokole rozpoczęcia, przebiegu i zakończenia każdej sprawy (prowadzenie ksiąg procesów);

- przyjmowanie dokumentów dostarczanych przez strony;

- wysyłanie wezwań i pism;

- troska o sporządzanie kompendiów procesów i dostarczanie ich sędziom;

- strzeżenie akt i dokumentów każdej sprawy;

- wysyłanie jednego egzemplarza akt sprawy - opatrzonego znakiem potwierdzającym autentyczność - do sądu apelacyjnego;

- przechowywanie $\mathrm{w}$ archiwum sądu oryginalnego egzemplarza akt i dokumentów;

- opatrywanie pieczęcią potwierdzającą autentyczność kopii każdego aktu lub dokumentu, gdy prosi o to osoba uprawniona;

- zwracanie dokumentów, zgodnie z art. 91, $\$ \$ 1-2$ DC, który stanowi, iż po zakończeniu procesu zwraca się dokumenty będące własnością osób prywatnych, zachowując ich uwierzytelnioną kopię ${ }^{14}$, za zgodą sędziego ${ }^{15}$.

\footnotetext{
13 Por. KPK kan. 484.

14 DC art. $91 \$ 1$.

15 DC art. $91 \$ 2$.
} 
Jak widać z przedstawionego katalogu działań, niektóre czynności notariusz podejmuje na polecenie sędziego, lecz jest też szereg czynności, które zgodnie z przepisami podejmuje z samodzielnie.

Analogicznie zakres zadań notariusza został ujęty w Regulaminie Sądu Diecezjalnego w Tarnowie z 2015 roku w pkt. 11:

„Do obowiązków notariusza należy:

1. sporządzanie akt;

2. redagowanie większości dokumentów według zleceń sędziego;

3. podpisywanie akt;

4. protokołowanie instrukcji procesu i dyskusji nad sprawą;

5. porządkowanie, gromadzenie i strzeżenie akt sądowych;

6. dokładne prowadzenie księgi spraw i księgi korespondencji;

7. pomoc w przeprowadzaniu czynności sądowych;

8.zapisywanie i protokołowanie faktów, oświadczeń i dyskusji mających miejsce w siedzibie Sądu, z podaniem ich daty, a także wykonywanie innych czynności, które wymagają jego udziału (por. kan. 484, 1472-1475 KРК)"16.

Jak widać, regulamin jeszcze dokładniej określił zakres działania notariusza. Taki katalog zadań pozwala na efektywną współpracę notariuszy między sobą i z sędziami, co powoduje znaczne przyspieszenie procesu. Wiele czynności notariusz podejmuje z własnej inicjatywy, jedynie konsultując ich podjęcie z sędzią. Zawsze, na polecenie sędziego, notariusz obowiązany jest sporządzić i przedstawić mu kompendium procesu ${ }^{17}$.

Kierownik kancelarii sądu powinien zdecydowanie powstrzymać się od jakiejkolwiek ingerencji w sprawie ponad to, co przysługuje mu z urzę$\mathrm{du}^{18}$, a pod jego nieobecność lub w czasie przeszkodzenia kierownika kancelarii sprawami odnoszącymi się do akt sądowych powinien zająć się inny notariusz ${ }^{19}$.

Notariusz (lub aktuariusz) powinien brać udział w każdym procesie, a za nieważne należy uznać akta, których notariusz nie podpisa ${ }^{20}$. Akta sporządzone przez notariusza są publicznie wiarygodne $e^{21}$.

\footnotetext{
${ }^{16}$ Regulamin Sądu Diecezjalnego w Tarnowie, „Currenda” 1 (2015), s. 55-61.

${ }^{17}$ DC art. $61 \$_{2}$.

${ }^{18}$ DC art. $61 \S_{3}$.

19 DC art. $61 \$ 4$.

${ }^{20}$ DC art. $62 \$ 1$, por. KPK kan. $1437 \$ 1$.

${ }^{21}$ DC art. $62 \$ 2$, por. KPK kan. $1437 \$ 2$; KPK kan. $1540 \$ 1$.
} 
$\mathrm{W} \$_{3}$ art. 62 DC przewiduje możliwość przydzielenia notariuszowi zastępcy na wypadek przeszkodzenia. Wzmianka o tym ma być umieszczona w aktach sprawy. W Sądzie Diecezjalnym w Tarnowie przepis ten od 2013 roku ma szerokie zastosowanie. W każdym procesie przydziela się notariuszowi zastępcę. Takie rozwiązanie istotnie usprawniło pracę sądu, ponieważ nie występuje obecnie sytuacja, kiedy podjęcie czynności procesowej musi być wstrzymane z powodu np. urlopu lub choroby notariusza ${ }^{22}$. Inną kwestią jest mianowanie zastępcy do poszczególnego aktu i ze słusznej przyczyny, zwłaszcza jeśli stronę lub świadka trzeba przesłuchać poza siedzibą sądu. Dokonuje tego sędzia, jego delegat lub audytor ${ }^{23}$.

$\mathrm{W}$ punkcie 3 opisano, jak wymienione zagadnienia realizują się w praktyce Sądu Diecezjalnego w Tarnowie.

\section{Procedura przyjęcia skargi powodowej}

Proces o stwierdzenie nieważności małżeństwa rozpoczyna się po przedstawieniu prośby przez tego, kto ma prawo zaskarżyć małżeństwo ${ }^{24}$. Jednak działania notariusza zaczynają się wcześniej.

Notariusz często jest pierwszą osobą, do której zwracają się strony z pytaniem (osobiście, telefonicznie, przez e-mail), gdzie można uzyskać poradę $\mathrm{w}$ sprawie o nieważność małżeństwa i jakie dokumenty należy złożyć, aby rozpocząć proces ${ }^{25}$. Fachowość i życzliwość w udzielaniu informacji sprawiają, że strony postrzegają sąd jako instytucję przyjazną i pomocną w rozwiązywaniu ich spraw życiowych.

W Sądzie Diecezjalnym w Tarnowie do 2007 roku poradnictwo przedprocesowe prowadzone było przez sędziów i notariuszy, czy to w siedzibie sądu, czy też w ramach poradni przy parafiach: katedralnej w Tarnowie i św. Małgorzaty w Nowym Sączu, czy też jako element rekolekcji dla małżeństw niesakramentalnych. Zwłaszcza od roku 2000 (Roku Jubileuszu) dało się zauważyć wzmożone zainteresowanie procesami o stwierdzenie

${ }^{22}$ Por. pkt 11 Regulaminu.

${ }^{23}$ DC art. $62 \$ 4$.

${ }^{24}$ DC art. 114; KPK kan 1501.

${ }_{25}$ Por. R. Sztychmiler, Ochrona praw człowieka w normach kanonicznego procesu spornego, Olsztyn 2003, s. 42. 
nieważności małżeństwa. Po części było to spowodowane większą zachętą ze strony kapłanów, po części propagowanymi w mediach informacjami na temat procesów. Aby zaradzić potrzebom, w samym sądzie zostały wprowadzone dyżury sędziów i notariusza, podczas których kolejno każdy pracownik udzielał porad, odkładając na jeden dzień w tygodniu swoje zwykłe zajęcia. Już wtedy dało się zauważyć, że udzielanie porad przez osobę świecką nie wzbudzało żadnych zastrzeżeń. Kiedy w 2007 roku przy Sądzie Diecezjalnym w Tarnowie zaczęła funkcjonować poradnia prawnokanoniczna, sędziowie i notariusz zostali zwolnieni z dyżurów $\mathrm{w}$ ramach poradnictwa, a strony były odsyłane na rozmowę $\mathrm{z}$ adwokatem stałym. Jednocześnie pojawiła się kwestia współpracy między notariuszem i adwokatem ${ }^{26}$.

Obecnie osoby zainteresowane uzyskaniem porady są najczęściej kierowane przez notariusza do adwokata stałego. Adwokat pomaga stronie zredagować skargę i wyjaśnia ogólne zasady prowadzenia procesu. Niezależnie jednak, czy strona korzysta z jego pomocy, czy też samodzielnie redaguje skargę, notariusz niejednokrotnie staje wobec konieczności wytłumaczenia pewnych trudności. Tak dzieje się na przykład, gdy poradę chcą uzyskać rodzice lub rodzeństwo strony, uzasadniając na bardzo różne sposoby nieobecność bezpośrednio zainteresowanego: pobyt za granicą, godziny pracy uniemożliwiające osobisty kontakt, nieśmiałość lub nieporadność. To notariusz informuje, że tylko strona może zaskarżyć swoje małżeństwo, a to oznacza konieczność osobistego działania, tym bardziej że tylko strona może w pełni przedstawić istotne fakty dotyczące jej małżeństwa ${ }^{27}$.

Dokumentem rozpoczynającym proces jest skarga powodowa. Każda skarga, czy to wysyłana pocztą, czy składana osobiście przez stronę w sekretariacie sądu, przechodzi przez ręce notariusza zgodnie z dyspozycją art. 61 \$2 DC. W latach 80. stosunkowo częstą formą sporządzania skargi była skarga ustna zaprotokołowana przez notariusza na podstawie kan. $1503 \mathrm{KPK} 1983^{28}$. Obecnie strony zwykle redagują skargę według wskazań

${ }^{26}$ Szerzej na ten temat zob. A. Czernia, Wspótpraca adwokata z notariatem. Spojrzenie z punktu widzenia notariusza kościelnego, [w:] Wspótpraca sądów ze stronami procesowymi i adwokatami, red. R. Sztychmiler, J. Krzywkowska, Olsztyn 2011, s. 197-205.

${ }^{27}$ KPK kan. 1501; DC art. 114.

${ }^{28}$ DC art. $115 \$ 2$, por. H. Sawniak, Wprowadzenie sprawy i zakończenie instancji według Instrukcji „Dignitas Connubii”, [w:] Proces małżeński według Instrukcji „Dignitas Connubii”. 
uzyskanych w Poradni Prawno-Kanonicznej przy Sądzie Diecezjalnym w Tarnowie lub w poradniach przy parafiach w Nowym Sączu i Tarnowie. Zdarza się też, że piszą skargę, korzystając z informacji znalezionych w różnych publikacjach lub na forach internetowych, bądź zwracają się po pomoc do adwokatów świeckich. Skarga sporządzona bez pomocy specjalisty może zawierać szereg braków, które stanowią podstawę do jej odrzucenia, zgodnie z art. 121 DC $^{29}$. Praktyka Sądu Diecezjalnego w tym względzie od lat była i pozostaje niezmienna. Przed odnotowaniem wpłynięcia takiej skargi, szczególnie gdy strona składa ją osobiście, notariusz podejmuje starania o usunięcie istniejących braków. Przegląda skargę i wskazuje to, co można usunąć na miejscu, np. brak podpisu strony powodowej (najczęściej występujący), brak adresu strony pozwanej, brak adresów świadków, lub objaśnia sposób usunięcia innych braków, także sugerując skorzystanie z pomocy adwokata stałego, np. gdy brak tytułu nieważności małżeństwa ${ }^{30}$. Takie działanie pozwala uniknąć odrzucenia skargi.

W sytuacji gdy skarga została przesłana pocztą, nie ma możliwości dokonania uzupełnień od razu. Jeśli skarga zawiera wady, które mogą być poprawione ${ }^{31}$, notariusz po konsultacji $\mathrm{z}$ wikariuszem sądowym podejmuje działania w kierunku ich uzupełnienia, np. wzywa stronę do sądu w celu podpisania skargi, zwraca się pisemnie o dosłanie brakujących danych (adresu strony pozwanej czy świadków) lub dokumentów. Podobnie wystosowuje prośbę do proboszcza o przesłanie autentycznego świadectwa ślubu, wymaganego według art. $116 \$ 2$ DC, jeżeli strona napotyka na trudności w jego uzyskaniu. Zdarza się, że strony (także proboszczowie) uważają, że świadectwem ślubu jest dokument wystawiony przez proboszcza celem przedłożenia w usc przy zawieraniu małżeństwa konkordatowego. Do notariusza należy wyjaśnienie, że do skargi powinien być dołączony autentyczny dokument wystawiony przez proboszcza na potrzeby procesu przed Sądem Diecezjalnym.

Podobnie ma się sprawa $\mathrm{z}$ kompetencją sądu do prowadzenia procesu. Notariusz informuje stronę, który trybunał jest kompetentny do

Materiały z ogólnopolskiego spotkania pracowników sądownictwa kościelnego w Gródku nad Dunajcem w dniach 13-14 czerwca 2005 roku, red. T. Rozkrut, Tarnów 2006, s. 76.

${ }^{29}$ KPK kan. $1505 \$ 2$.

${ }^{30}$ KPK kan. 1504 n. 2; DC art. $116 \$ 1$.

${ }_{31}$ DC art. 123; KPK kan. $1505 \$ 3$. 
rozpatrzenia jej sprawy, czyli gdzie powinna złożyć skargę. Jeśli jednak strona przedstawia argumenty przemawiające za prowadzeniem procesu $\mathrm{w}$ trybunale tarnowskim, notariusz na polecenie wikariusza sądowego uruchamia procedurę uzyskania od właściwego trybunału zgody na prowadzenie procesu ${ }^{32}$.

Kompletną skargę powodową notariusz opatruje pieczęcią wpływu ( $\mathrm{z}$ datą), wpisuje do rejestru skarg wpływających ${ }^{33}$ i przekazuje wikariuszowi sądowemu. Następnie na polecenie przewodniczącego lub ponensa, ustanowionych przez wikariusza na podstawie art. 118 DC, sporządza dekret, na mocy którego strony pozywane są dla zawiązania sporu, powiadamiane o składzie trybunału i formule wątpliwości ${ }^{34}$ oraz informowane o możliwości złożenia oświadczenia ustnie wobec sędziego (zwykle protokół z oświadczenia ustnego sporządza notariusz) lub na piśmie. Fakt wydania dekretu notariusz odnotowuje w księdze procesów ${ }^{35}$.

W sądzie tarnowskim przez szereg lat skargi przyjmował osobiście wikariusz sądowy. To on dysponował pieczęcią wpływu i troszczył się o nadanie biegu nowej sprawie w przewidzianym terminie lub o przekazanie jej do uzupełnienia. Do rejestru w tym czasie wpisywane były tylko sprawy oddalone. Wraz ze wzrostem liczby wpływających skarg praktyka ulegała zmianie. Skargi składane przez strony przyjmował notariusz w sekretariacie sądu i przekazywał wikariuszowi sądowemu, skargi napływające pocztą przyjmował wikariusz sądowy. Od 2002 roku notariusz na stałe został upoważniony do przyjmowania skarg, nadawania im daty wpływu i uzupełniania tych niekompletnych. Rejestr spraw wpływających (w wersji elektronicznej) powstał dopiero w 2007 roku. W rejestrze oznaczone są imiona i nazwiska stron, data i parafia ślubu, data wpłynięcia skargi, a ponadto data wystawienia dekretu przyjęcia skargi.

Warto zwrócić uwagę na jeszcze jeden stosowany w dawniejszej praktyce element. Przed ukonstytuowaniem trybunału na polecenie wikariusza sądowego notariusz przesyłał do strony pozwanej pismo powiadamiające

${ }^{32}$ KPK kan. 1673; DC art. 10.

${ }^{33}$ DC art. 61 \$2; por. M. Greszata, Rola i zadania notariusza sądowego, [w:] Urzędy sq̨dowe - władza i służba. Materiały z ogólnopolskiego spotkania pracowników sądownictwa kościelnego w Gródku nad Dunajcem w dniach 11-12 października 2004 roku, red. T. Rozkrut, Tarnów 2005, s. 68.

${ }^{34}$ DC art. 126-127; KPK kan. 1507-1508.

35 DC art. $61 \$ 2$. 
o wpłynięciu skargi, jej uprawnieniach związanych z tym faktem, oraz załączał kopię skargi powodowej ${ }^{36}$. Pismo takie, mimo iż nie było przewidziane w przepisach KPK 1983 i DC, przynosiło szereg korzyści dla stron i sądu. Strona pozwana otrzymywała sygnał, że jest pełnoprawnym uczestnikiem procesu (co dla wielu osób wcale nie jest oczywiste), a jej stanowisko jest brane pod uwagę na równi ze stanowiskiem strony powodowej. Strona powodowa otrzymywała wiadomość, że sąd podjął działanie w procesie, dlatego wykazywała większą cierpliwość w sytuacji, gdy oczekiwanie na dekret przyjęcia skargi przekraczało, nawet znacznie, przewidziane w przepisach $30 \mathrm{dni}^{37}$. Sąd z kolei zyskiwał potwierdzenie, że adres strony pozwanej jest prawidłowy, lub informację, że zachodzi konieczność podjęcia starań o uzyskanie aktualnego adresu. W razie konieczności starania się o zgodę na prowadzenie procesu, według dyspozycji kan. 1673 n. 4 KPK 1983, wzmiankowane pismo kierowane do strony pozwanej za pośrednictwem właściwego trybunału stanowiło podstawę analizy sytuacji i wyrażenia bądź niewyrażenia zgody. Odpowiedź strony pozwanej, często po zasięgnięciu porady w sądzie, umożliwiała dokładniejsze rozeznanie $\mathrm{w}$ sprawie i ułatwiała sformułowanie wątpliwości. Po wejściu w życie DC zasadność tej praktyki była coraz częściej podawana w wątpliwość. Ostatecznie przeważyło stanowisko o konieczności dostosowania praktyki sądowej do przepisów DC i dlatego zaniechano wysyłania tego „nadprogramowego" pisma.

Obecnie kopia skargi powodowej jest udostępniana stronie pozwanej w siedzibie sądu lub doręczana wraz z dekretem przyjmującym skargę i pozywającym ją do udzielenia odpowiedzi na żądania strony powodowej $^{38}$. Najczęściej proszona jest o udzielenie pisemnej odpowiedzi, jednak dopuszczalne jest też udzielenie odpowiedzi ustnej, którą protokołuje notariusz. Dekret przesyłany jest, zgodnie z art. $130 \$ 1 \mathrm{DC}$, za pośrednictwem poczty (konkretnie Poczty Polskiej) listem poleconym na adres strony lub jej pełnomocnika, jeśli został ustanowiony ${ }^{39}$. Dowód nadania listu dołączany jest do akt sprawy ${ }^{40}$. Niestety ze względu na wysokie opłaty

${ }^{36}$ Por. KPK kan. 1494.

${ }^{37}$ KPK kan. 1506; DC art. 125.

${ }^{38}$ KPK kan. 1507; DC art. 126, por. pkt 13 Regulaminu.

39 DC art. 131.

${ }^{40}$ DC art. $130 \$ 2$; pkt 14 Regulaminu, por. R. Sztychmiler, Ochrona praw człowieka $w$ normach kanonicznego procesu spornego, dz. cyt. s. 83 . 
pocztowe tylko część pism procesowych nadawana jest przesyłką poleconą, a jeszcze mniej za zwrotnym potwierdzeniem odbioru. Część pism nadaje się jako przesyłki zwykłe, lecz to nie zmniejsza skuteczności doręczeń. Zalecenie stosowania zwrotnego potwierdzenia odbioru straciło nieco na znaczeniu, odkąd Poczta Polska uruchomiła e-usługę umożliwiającą monitorowanie przesyłek poleconych tak w kraju, jak i za granicą.

Doręczenie korespondencji czasami nastręcza trudności. I tak w przypadku gdy adresat odmawia przyjęcia korespondencji, zgodnie z art. 133 DC uważa się, iż został prawidłowo wezwany i poinformowany o sprawie. Mimo to, jeśli skontaktuje się z sądem np. telefonicznie, choćby po to, by wyrazić swoje oburzenie, notariusz powinien sporządzić notatkę z rozmowy (zawierającą datę i podpis notariusza), która jest potwierdzeniem, że strona wie o procesie. Jeśli korespondencja zostanie zwrócona $\mathrm{z}$ adnotacją „Adresat nieobecny. Nie podjęto w terminie”, notariusz w porozumieniu z przewodniczącym trybunału wystosowuje prośbę do właściwego proboszcza o skontaktowanie się ze stroną. Zwykle w odpowiedzi proboszcz przesyła pisemne potwierdzenie odebrania korespondencji przez stronę lub informację, iż strona nie mieszka pod wskazanym adresem. Ta ostatnia informacja jest $\mathrm{z}$ kolei podstawą do zastosowania art. 132 DC, tzn. podjęcia „starannych poszukiwań” i publicznego obwieszczenia wezwania i zawiadomienia. „Staranne poszukiwania” obejmują współpracę notariusza i strony powodowej, a odbywają się za pośrednictwem wydziału spraw obywatelskich urzędu miasta lub gminy ostatniego miejsca zamieszkania strony pozwanej (dawniej Centralnego Biura Adresowego) w Polsce lub właściwej ambasady (konsulatu), gdy strona pozwana przebywa za granicą. Istotne są wszelkie dokumenty potwierdzające bezskuteczność poszukiwań strony, np. oświadczenie komornika (dawniej Funduszu Alimentacyjnego) o bezskuteczności postępowania w sprawie zaległych alimentów, oświadczenie organów policji lub sądu karnego. Bardzo ważne jest oświadczenie krewnych strony pozwanej. Notariusz zachęca do kontaktu stronę powodową lub sam przesyła zapytanie w porozumieniu z wikariuszem sądowym. Przeprowadzenie takich poszukiwań jest podstawą do publicznego obwieszczenia (per edictum) wezwania i zawiadomienia ${ }^{41}$ oraz kontynuowania procesu ${ }^{42}$.

\footnotetext{
${ }^{41}$ DC art. $132 \$ 2$.

42 DC art. $132 \$ 1$.
} 


\section{Procedura ustalenia przedmiotu sporu}

Ustalenie przedmiotu sporu dokonywane jest przez Sędziego w formie dekretu ${ }^{43}$. Sędzia bierze pod uwagę pisemne i ustne wypowiedzi stron ${ }^{44}$.

W praktyce sądu tarnowskiego przed 2005 rokiem spora część czynności prowadzących do ustalenia przedmiotu sporu była wykonywana jeszcze przed wydaniem dekretu cytacyjnego. Jak już była mowa wyżej, strona pozwana otrzymywała wcześniej skargę powodową, miała możliwość odniesienia się do zawartych w niej zarzutów i wniesienia nowego tytułu nieważności małżeństwa. Po dostosowaniu praktyki do wymagań DC przedkładanie zarzutów bądź nowego tytułu odbywa się w ciągu 15 dni od wydania dekretu cytacyjnego. Często w odpowiedzi na pytanie strony pozwanej notariusz redaguje na polecenie przewodniczącego trybunału (poprzednio wikariusza sądowego) pismo, w którym wyjaśnia jej uprawnienia w procesie. Także do notariusza należy zaprotokołowanie ustnego oświadczenia strony powodowej i pozwanej, chyba że strona wprost domaga się złożenia oświadczenia wobec sędziego ${ }^{45}$. Po ustaleniu przedmiotu sporu sędzia wydaje notariuszowi polecenie sporządzenia dekretu i podania go do wiadomości stronom. Najczęściej odbywa się to pocztą poleconą, rzadziej strona osobiście odbiera dekret w sekretariacie sądu. Strony, jeśli poprzednio nie wyraziły zgody na przedmiot sporu, mogą $\mathrm{w}$ terminie 10 dni prosić o jego zmianę $e^{46}$. Instrukcja DC poleca odwołać się do kolegium (art. 135, \$4 DC). Nieco inaczej (odwołanie do samego sędziego) ujmuje to КРК (art. 1513, \$3 К РК). W praktyce zwykle to sędzia podejmuje decyzję o uwzględnieniu wniosku i poleca notariuszowi sporządzić kolejny dekret. Dotychczas tylko raz zaistniała sytuacja, gdy powód odwołał się o zmianę dekretu zawiązania sporu do kolegium sędziowskiego i od kolegium otrzymał odpowiedź.

Fakt wydania dekretu zawiązania sporu, podobnie jak fakt zmiany przedmiotu sporu, notariusz odnotowuje w księgach procesowych ${ }^{47}$. Jeżeli strona właściwie powiadomiona nie stawi się na wezwanie i nie

43 KPK kan. $1513 \$ 1$; DC art. $135 \$ 1$.

${ }^{44}$ KPK kan. $1513 \$ 2$; DC art. $135 \$ 2$.

45 DC art. $135 \$ 2$; KPK kan. $1513 \$ 2$.

${ }^{46}$ Por. R. Sztychmiler, Ochrona praw człowieka w normach kanonicznego procesu spornego, dz. cyt., s. 89.

47 DC art. $61 \$ 2$. 
przedstawi usprawiedliwienia nieobecności ani nie prześle pisemnej odpowiedzi, przewodniczący lub ponens orzeka jej nieobecność w sądzie i zarządza prowadzenie sprawy aż od wydania ostatecznego wyroku ${ }^{48}$, $\mathrm{z}$ zachowaniem art. $138 \$ 3 \mathrm{DC}$ (ponowne wezwanie stron).

W Sądzie Diecezjalnym w Tarnowie przed 2005 rokiem była praktyka wydawania dekretu ogłaszającego nieobecność strony pozwanej w procesie przed zawiązaniem sporu. Mimo wydania takiego dekretu strona była wzywana do złożenia zeznań i powiadamiana o kolejnych czynnościach podejmowanych $\mathrm{w}$ procesie. To znacznie przedłużało proces, ponieważ strona pozwana często nie udzielała żadnej odpowiedzi. Wprowadzenie w życie wskazań DC wpłynęło na modyfikację tego elementu. Obecnie dekret ogłoszenia nieobecności strony pozwanej wystawiany jest, jeśli strona dwukrotnie nie stawiła się do złożenia zeznań, o ile nie nadesłała usprawiedliwienia. Notariusz na polecenie sędziego sporządza dekret i przesyła stronie ${ }^{49}$. Także do notariusza należy zatroszczenie się o to, aby strona ogłoszona nieobecną otrzymała w przewidzianym czasie informację o wyroku ${ }^{50}$.

Nieco inaczej wygląda sytuacja, jeśli strona pozwana wyraźnie oświadczy, że nie chce brać udziału w procesie i zdaje się na decyzję sędziów. Wówczas wydawany jest dekret nieobecności, jednak strona zachowuje prawo do uzyskiwania informacji o kolejnych etapach procesu ${ }^{51}$.

\section{Procedura dowodzenia}

Po ustaleniu przedmiotu sporu ${ }^{52}$ ponens zarządza rozpoczęcie instrukcji dowodowej $j^{53}$. Notariusz sporządza na jego polecenie stosowny dekret, odnotowuje ten fakt w księgach procesów, a następnie przekazuje akta do obrońcy węzła małżeńskiego (praktyka sądu tarnowskiego), aby ten mógł, zgodnie z art. $164 \mathrm{DC}^{54}$, przedstawić zagadnienia, co do których powinny być zapytane strony i świadkowie (biegli). DC nie wymaga wprost,

\footnotetext{
${ }^{48}$ DC art. $138 \$ 1$.

49 DC art. 131 i KPK kan. 1592.

${ }^{50}$ DC art. $134 \$ 3$.

51 DC art. $134 \$ 2$.

52 DC art. 135; por. KPK kan. 1677 i KPK kan. 1513.

53 DC art. 137; por. KPK kan. $1677 \$ 4$.

54 Por. кРК kan. 1533.
} 
aby to obrońca układał pytania do procesu, może zrobić to audytor. Jednak wydaje się pożyteczne, aby obrońca już na tym etapie sprawy miał możliwość podniesienia szczegółowych kwestii, które jego zdaniem wymagają wyjaśnienia w trakcie instrukcji dowodowej.

Po sporządzeniu pytań przez obrońcę lub audytora rozpoczyna się etap zbierania materiału dowodowego. Notariusz na polecenia sędziego wysyła wezwania do złożenia zeznań przez strony i świadków ${ }^{55}$.

Fragment wypowiedzi z 2007 roku oznajmiał: „Art. 166 DC $^{56}$ stanowi, iż przesłuchaniom, dokonywanym przez sędziego, jego delegata lub audytora, ma towarzyszyć notariusz. Niestety, w praktyce sądu tarnowskiego, zachowanie tego przepisu jest sytuacją wyjątkową. Usprawiedliwieniem może być fakt, iż Sąd tarnowski ma tylko jednego notariusza, a codziennie odbywa się kilka (4-5) przesłuchań w tym samym czasie. Ponieważ jednak nieobecność notariusza nie powoduje nieważności przesłuchania, w praktyce notariusz czyta i podpisuje zeznania ex post. Zresztą tylko jeden raz w ciągu piętnastu lat przesłuchiwany zwrócił uwagę na ten

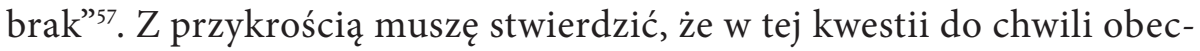
nej nic się nie zmieniło. Mimo pracy dwu notariuszy nadal niemożliwe jest uczestniczenie we wszystkich przesłuchaniach. Wprawdzie liczne argumenty przemawiają za koniecznością zmiany tej praktyki, z całą pewnością jednak niewystarczającym argumentem wydaje się konieczność uwierzytelnienia i ponumerowania akt ${ }^{58}$. Chodzi raczej o ochronę audytora i przesłuchiwanego przed np. zarzutem próby przekupstwa. Mimo to audytorzy podnoszą szereg argumentów za utrzymaniem dotychczasowej praktyki, np. nieobecność notariusza stwarza korzystne warunki do szczerej wypowiedzi zeznającego, usuwa poczucie skrępowania, zwłaszcza gdy chodzi o przesłuchanie dotykające sfery intymnej strony lub świadka.

Przed przesłuchaniem strona lub świadek składają przysięgę (lub obietnicę) mówienia prawdy ${ }^{59}$. Notariusz odnotowuje ten fakt w aktach sprawy.

${ }^{55}$ DC art. $61 \$ 2$.

${ }^{56}$ Por. KPK kan. 1561.

57 A. Czernia, Zadania notariusza $w$ procesie małżeńskim (na przykładzie sądu biskupiego w Tarnowie), [w:] Zagadnienia kościelnego prawa majątkowego i procesowego, red. E. Szczot, S. Białek, Lublin 2008, s. 173.

${ }^{58}$ Por. M. Greszata, Rola..., dz. cyt., s. 76-77.

59 Por. DC art. $167 \$ \$ 2-3$; KPK kan. $1562 \$ 1$. 
Według dyspozycji art. $174 \mathrm{DC}^{60}$ umieszcza tam również informację o odmowie złożenia przysięgi, o obecności obrońcy węzła małżeńskiego lub adwokatów, o pytaniach dodanych z urzędu oraz o wszelkich faktach godnych odnotowania, które miały miejsce w czasie przesłuchania. Odpowiedzi przesłuchiwanego spisuje niezwłocznie, pod kierunkiem sędziego, starając się o zachowanie dosłownego brzmienia słów zeznającego przynajmniej odnośnie do tego, co bezpośrednio dotyczy przedmiotu sprawy $^{61}$. W praktyce najczęściej sędzia samodzielnie zapisuje zeznania lub formułuje zdania, które następnie zapisuje notariusz ${ }^{62}$. W trakcie przesłuchania dopuszczalne jest użycie magnetofonu albo innego urządzenia nagrywającego. W takim przypadku odpowiedzi mają być niezwłocznie spisane i w miarę możliwości podpisane przez zeznającego ${ }^{63}$.

Po zakończeniu przesłuchania notariusz powinien odczytać przesłuchiwanemu treść spisanych zeznań ${ }^{64}$, aby umożliwić uzupełnienie, skreślenie, poprawienie lub zmiany w zeznaniach. W praktyce zeznający najczęściej samodzielnie czyta wydrukowane zeznanie i zgłasza, co w zeznaniu chciałby uzupełnić, zmienić lub poprawić. Tylko w wyjątkowych sytuacjach, np. osób starszych, które nie zabrały okularów, lub osób, które w ogóle mają trudności z czytaniem, zeznanie odczytuje notariusz ${ }^{65}$.

Zeznanie podpisują: zeznający, sędzia i notariusz, a także obrońca węzła, promotor sprawiedliwości i adwokat, jeśli uczestniczyli w przesłuchaniu ${ }^{66}$. Jeżeli pojawią się jakiekolwiek trudności w podpisaniu zeznania przez przesłuchiwanego, notariusz swoim podpisem potwierdza autentyczność postawionych znaków i wyjaśnia przyczynę ich postawienia ${ }^{67}$. Dotychczas tylko raz zanotowano przypadek potwierdzenia przez notariusza znaków osoby niepiśmiennej. Wydaje się, że ten problem zaniknął, ponieważ

\footnotetext{
${ }^{60}$ Por. KPK kan. 1568.

${ }^{61}$ DC art. $173 \$ 1 ;$ KPK kan. $1567 \$ 1$.

${ }^{62}$ Por. R. Sztychmiler, Ochrona praw człowieka w normach kanonicznego procesu spornego, dz. cyt., s. 176-178.

${ }_{63}$ DC art. $173 \$ 2$; KPK kan. $1567 \$ 2$.

${ }^{64}$ DC art. $175 \$ 1$; KPK kan. $1569 \$ 1$.

${ }^{65}$ Por. R. Sztychmiler, Ochrona praw człowieka w normach kanonicznego procesu spornego, dz. cyt., s.179-18o.

${ }_{66}$ DC art. $175 \$ 2$; por. KPK kan. $1569 \$ 2$.

${ }^{67}$ DC art. 89; por. KPK kan. 1473, por. R. Sztychmiler, Ochrona praw człowieka $w$ normach kanonicznego procesu spornego, dz. cyt., s. 180.
} 
wszyscy potrafią pisać, a przynajmniej podpisać się. Natomiast kilka razy miało miejsce potwierdzenie autentyczności podpisu nieczytelnego wskutek np. poważnej choroby oczu, zaawansowanej choroby układu nerwowego (niekontrolowane drżenie rąk), złamania ręki. Wydaje się, że ten przepis będzie miał zastosowanie także w przypadku odcisku palca osoby trwale sparaliżowanej, mimo że przepis prawa cywilnego traktuje odcisk jako autentyczny podpis ${ }^{68}$.

Jeżeli w czasie przesłuchania zeznania były nagrywane, art. $175 \$_{3}$ DC wymaga, aby notariusz sporządził akt uwiarygodniający taką formę. Akt ten mają podpisać te same osoby, które podpisują protokół zeznania ${ }^{69}$. Do obowiązków notariusza należy takie opieczętowanie rejestracji, aby była uważana za autentyczną, i takie przechowywanie, aby była zachowana w miejscu bezpiecznym i w sposób integralny ${ }^{70}$.

W sądzie tarnowskim nie było i nie ma praktyki nagrywania zeznań. Kwestia pojawia się, gdy nagranie zeznań sąd otrzymuje z niektórych sądów w USA i Kanadzie. W takim przypadku notariusz zajmuje się sporządzeniem pisemnej wersji zeznań i uwierzytelnieniem ich oraz dołączeniem do akt sprawy. Niejednokrotnie jakość nagrania sprawia, że sporządzenie wiernego zapisu jest utrudnione. Często też, ze względu na sposób prowadzenia przesłuchania, nie ma możliwości oddzielenia pytań audytora od zeznań przesłuchiwanego, bo odpowiedzi oddzielone od pytań tracą sens.

Strony i świadkowie powinni złożyć zeznania w siedzibie sądu prowadzącego proces ${ }^{71}$. O ile nie budzi wątpliwości wzywanie osób mieszkających na terenie diecezji, o tyle strony i świadkowie mieszkający poza diecezją tarnowską często proszą o możliwość złożenia zeznań w innym miejscu. Praktyką sądu tarnowskiego jest wzywanie do siedziby sądu również osób mieszkających w sąsiednich diecezjach, np. krakowskiej, rzeszowskiej, sandomierskiej. Zeznanie odebrane przez audytora w siedzibie sądu wydaje się pełniejsze niż zeznanie rekwizycyjne, nawet najlepiej wykonane. Kwestia ta dotyczy szczególnie strony powodowej. Jej zeznanie ukierunkowuje cały proces, dlatego audytorzy sądu tarnowskiego

\footnotetext{
${ }^{68}$ Kodeks cywilny, art. 79.

${ }^{69}$ DC art. $175 \$ 2$; KPK kan. $1569 \$ 2$.

${ }^{70}$ DC art. $175 \$ 3$.

${ }^{71}$ DC art. $162 \$ 1$; por. KPK. kan. $1558 \$ 1$.
} 
proponują, aby strona podjęła trud i przybyła do siedziby sądu ${ }^{72}$. Jeśli jednak strona lub świadek mieszkają zbyt daleko lub stan zdrowia nie pozwala im na podróżowanie, istnieje możliwość skorzystania z wzajemnej pomocy prawnej sądów ${ }^{73}$ i odebrania zeznań w trybunale innej diecezji. Wówczas, na polecenie sędziego, notariusz sporządza kopię pytań i przesyła ją wraz z prośbą o przesłuchanie do właściwego trybunału. Jeśli zachodzą przesłanki do przesłuchania poza siedzibą sądu świadka mieszkającego w diecezji tarnowskiej (np. ze względu na stan zdrowia), sędzia poleca notariuszowi sporządzić pismo ustanawiające audytorem proboszcza miejsca zamieszkania świadka ${ }^{74}$. Przesłuchanie odbywa się wówczas w kancelarii parafialnej, choć zdarzają się przypadki, gdy konieczne jest przesłuchanie obłożnie chorej osoby w miejscu jej zamieszkania ${ }^{75}$.

Do czasu upowszechnienia internetu ustalenie właściwego sądu, zwłaszcza za granicą, było bardzo trudne. Zadaniem notariusza było przewertowanie spisu diecezji świata, aby ustalić prawdopodobną diecezję zamieszkania świadka. Korespondencja była wysyłana na adres kurii diecezjalnej z prośbą o przekazanie do właściwego trybunału. Niektóre sądy zagraniczne nadal proszą o pośrednictwo kancelarię kurii. Obecnie prawie wszystkie diecezje w Polsce i na świecie mają własne strony internetowe. Notariusz ma ułatwione zadanie, bo znacznie łatwiej przewertować elektroniczny spis, aby odszukać diecezję zamieszkania strony czy świadka i ustalić adres właściwego trybunału. Co więcej, korzystając ze spisów internetowych, można nawet ustalić, czy w pobliżu trybunału funkcjonuje parafia polska (chodzi o możliwość przesłuchania w języku polskim).

W latach 90. prośba o przesłuchanie do sądu za granicą była zwykle redagowana po łacinie, natomiast załączone pytania były po polsku. Obecnie zasadą jest przesyłanie prośby o przesłuchanie i pytań we własnym języku (język polski). Jeśli jednak strona czy świadek posługuje się innym językiem, dobrze jest przetłumaczyć pytania na ten właśnie język.

${ }^{72}$ Por. R. Sztychmiler, Ochrona praw człowieka w normach kanonicznego procesu spornego, dz. cyt., s. 141.

73 DC art. $29 \$ 1$; KPK kan. 1418.

74 DC art. $161 \$ 1$; por. KPK kan. 1528.

75 DC art. $162 \$ 3$; por. KPK kan. $1558 \$_{3}$. 
Jeżeli strona pozwana nie zgłosiła się do zeznań, sędzia wyznacza kolejny termin, a jeśli i ten okaże się bezskuteczny, zarządza wystawienie dekretu nieobecności strony pozwanej. Notariusz sporządza dekret i przesyła stronie pozwanej. Kolejną informacją wysłaną do strony pozwanej jest zawiadomienie o wydanym wyroku. O innych czynnościach $\mathrm{w}$ procesie strona pozwana nie jest informowana, co znacznie przyspiesza przebieg procesu ${ }^{76}$.

Ważnym rodzajem dowodów, obok zeznań, są dowody z dokumentów ${ }^{77}$. Mają one walor obiektywności i bezstronności w porównaniu $\mathrm{z}$ dowodem z zeznań. Dokumenty mogą mieć charakter publiczny ${ }^{78}$ (np. świadectwo ślubu) i te mają walor pełnego dowodu ${ }^{79}$. Dokumenty prywatne, np. listy stron czy umowy, mają charakter prywatny nawet wtedy, gdy zostały uwiarygodnione przez notariusza ${ }^{80}$. Takie dokumenty prywatne maja niejednokrotnie istotne znaczenie dla rozstrzygnięcia sprawy, o ile zostały złożone w oryginale lub gdy zostały uwierzytelnione przez notariusza ${ }^{81}$.

$\mathrm{W}$ wielu procesach istotnym dowodem jest opinia biegłego. Notariusz często spełnia rolę pośrednika między biegłym i sędzią, przekazując akt nominowanemu biegłemu ${ }^{82}$, ustalając termin badania strony itp. Niektórzy biegli współpracujący z Sądem Diecezjalnym w Tarnowie dysponują własnymi gabinetami i samodzielnie wzywają strony na badanie. Wezwanie od nieznanej osoby może budzić wątpliwość, a co za tym idzie brak zaufania wobec biegłego. Powiadomienie stron o nominacji biegłego pozwoli tego uniknąc $c^{83}$. Nieco inaczej wygląda sytuacja, gdy biegły w czasie

${ }^{76}$ DC art. $134 \$_{3}$.

77 DC art. 183; KPK kan. 1539.

${ }_{78}$ DC art. 184; KPK kan. 1540.

79 DC art. 185 \$1; KPK kan. 1541; por. R. Sztychmiler, Ochrona praw człowieka w normach kanonicznego procesu spornego, dz. cyt., s. 151.

${ }^{80}$ DC art. $185 \$ \$ 2-3$; KPK kan. 1542.

${ }^{81}$ DC art. 190; KPK kan. 1544, por. T. Rozkrut, Dowody w kanonicznym procesie małżeńskim według Instrukcji „Dignitas connubii”, [w:] Proces małżeński według Instrukcji „Dignitas connubii”. Materiały z ogólnopolskiego spotkania pracowników sądownictwa kościelnego w Gródku nad Dunajcem w dniach 13-14 czerwca 2005 roku, red. T. Rozkrut, Tarnów 2006, s. 103-104.

${ }^{82}$ DC art. $204 \$ 1$; KPK kan. 1575; por. R. Sztychmiler, Ochrona praw człowieka $w$ normach kanonicznego procesu spornego, dz. cyt., s. 189-19o.

${ }^{83}$ DC art. $204 \$ 2$. 
badania korzysta z pomieszczeń sądu. Wówczas notariusz, po ustaleniu z biegłym terminu badania, wysyła wezwanie podpisane przez sędziego ${ }^{84}$.

Po zebraniu materiału dowodowego sędzia dokonuje publikacji akt ${ }^{85}$. $\mathrm{Na}$ jego polecenie notariusz sporządza dekret zezwalający stronom i ich adwokatom na przejrzenie akt lub tych dokumentów, które jeszcze nie są im znane ${ }^{86}$. Z ważnych przyczyn sędzia może zdecydować, aby nie ujawniać stronom jakiegoś aktu ${ }^{87}$. W praktyce zgodnie $\mathrm{z}$ tą dyspozycją notariusz jako sprawujący pieczę nad aktami procesu ${ }^{88}$ przygotowuje akta w taki sposób, aby utajnione dokumenty nie zostały ujawnione stronom. Utajniony dokument może być przejrzany przez adwokatów stron ${ }^{89}$.

Do 2007 roku przepis o ujawnieniu akt adwokatowi zasadniczo nie był realizowany z powodu braku adwokatów. W tym okresie, w szczególnych sytuacjach i z ważnej przyczyny, sędzia dopuszczał możliwość ustanowienia przez stronę pełnomocnika (najczęściej członka rodziny), który otrzymywał zgodę na zapoznanie się z aktami sprawy (jednak bez dokumentów utajnionych) i przekazanie stronie informacji umożliwiających przygotowanie głosu obrończego. Działanie takie nie znajdowało uzasadnienia w prawie, a jedynie w ogólnej zasadzie troski o dobro dusz. Uzdrowieniem tej sytuacji było ustanowienie adwokata stałego przy Sądzie Diecezjalnym w Tarnowie, który może być upoważniony do reprezentowania strony przed sądem ${ }^{90}$. Adwokat może zapoznać się z materiałem dowodowym, łącznie z dokumentami utajnionymi, może też uzyskać odpis akt pod warunkami określonymi w art. $235 \mathrm{DC}^{91}$. To samo odnosi się do adwokatów zatwierdzanych ad casum, jako że w Sądzie Diecezjalnym w Tarnowie nie ma listy adwokackiej wymienionej w art. 112 $\$ 1$ DC. Nie jest natomiast możliwe, aby członkowie rodziny zapoznawali się z aktami sprawy, mimo że niejednokrotnie domagają się tego, powołując się na fakt składania zeznań.

${ }^{84}$ DC art. $61 \$ 1$.

85 DC art. $229 \$ 1$, por. KPK kan. $1598 \$ 1$.

86 DC art. 229 \$\$ 2-3; KPK kan. 1598 \$1, por. pkt 17 Regulaminu.

87 DC art. 230; por. KPK kan. $1598 \$ 1$; R. Sztychmiler, Ochrona praw człowieka w normach kanonicznego procesu spornego, dz. cyt., s. 199.

${ }^{88}$ DC art. $61 \$ 2$.

${ }^{89}$ DC art. 234.

90 DC art. 101; por. KPK kan. $1481 \$ 1$.

91 Por. крк kan. $1598 \$ 1$. 
Zapoznanie się z materiałem dowodowym odbywa się w kancelarii sądu w obecności notariusza i w terminie wyznaczonym przez sędziego w dekrecie $e^{92}$. Na wniosek strony termin może być przedłużony, jednak w sposób wykluczający przewlekanie sprawy. Od lutego 2015 roku, przed zapoznaniem się z aktami stronę zobowiązuje się przysięgą (lub przyrzeczeniem), składaną na piśmie wobec notariusza, do zachowania tajemnicy odnośnie do uzyskanych wiadomości i korzystania z nich jedynie $\mathrm{w}$ celu przygotowania obrony w procesie ${ }^{93}$. Jednocześnie strona informowana jest o zakazie wykonywania kopii czy zdjęć poszczególnych kart procesu ${ }^{94}$. Ułatwia to wyjaśnienie stronom, urażonym treścią materiału dowodowego, że akta sprawy nie mogą służyć do wniesienia przed sąd cywilny skargi o zniesławienie, tym bardziej że zebranym dowodom nie można przypisać charakteru publicznego, skoro są objęte klauzulą tajności i dostęp do nich ma ściśle określona grupa osób.

Jeśli strona zamieszkuje daleko od siedziby sądu, może przejrzeć akta $\mathrm{w}$ trybunale, na terenie którego zamieszkuje, lub w innym stosownym miejscu ${ }^{95}$. Na wniosek strony sędzia zarządza taką publikację, a notariusz, działając na mocy art. $61 \$ 2 \mathrm{DC}$, sporządza uwierzytelnioną kopię akt i przesyła ją do właściwego trybunału.

Po zapoznaniu się z aktami sprawy strony mogą wnieść prośbę o uzupełnienie materiału dowodowego o dalsze zeznania świadków lub nową opinię biegłego. Jeśli sędzia uzna to za konieczne, uzupełnia materiał dowodowy i zarządza ponowne ogłoszenie akt ${ }^{96}$.

\section{Procedura dyskusji sprawy}

Jeśli po zapoznaniu się z materiałem dowodowym strony nie złożyły wniosku o nowe dowody, sędzia po upływie wyznaczonego terminu zarządza dekretem zamknięcie postępowania dowodowego ${ }^{97}$. Równocześnie wyznacza stronom, ich adwokatom i obrońcy węzła małżeńskiego

${ }^{92}$ DC art. 233, \$1; por. KPK kan. $1598 \$ 1$.

93 Pkt 18 Regulaminu.

${ }^{94}$ Pkt 18 Regulaminu; por. DC art. 91 \$2 і KPK kan. $1475 \$ 2$.

${ }^{95}$ DC art. $233 \$ 2$.

${ }_{96}$ DC art. 236; por. KPK kan. $1598 \$ 2$.

97 DC art. 237; por. KPK kan. 1599, por. R. Sztychmiler, Ochrona praw człowieka w normach kanonicznego procesu spornego, dz. cyt., s. 200-201. 
odpowiedni czas na złożenie obron i uwag ${ }^{98}$. Treść dekretu notariusz przekazuje do wiadomości stron i ich adwokatów, a następnie przyjmuje składane przez nich głosy obrończe. Strony, które prowadzą proces bez pomocy adwokata, często zwracają się do notariusza z pytaniem, co należy rozmieć pod pojęciem „obrona” i czy składanie głosu obrończego jest konieczne. Warto zachęcić strony do skorzystania z tego uprawnienia, jednocześnie wyjaśniając, że chodzi tu o pismo, w którym strona, opierając się wyłącznie o zebrany materiał dowodowy, jeszcze raz przedstawia swoje stanowisko w celu wskazania wszystkich istotnych jej zdaniem argumentów dla sprawiedliwego wyroku ${ }^{99}$.

Praktyka sądu tarnowskiego przewiduje, iż strony mogą zapoznać się ze złożonymi pismami obrończymi w kancelarii sądu, natomiast uwagi obrońcy węzła małżeńskiego przesyłane są do stron na mocy postanowienia sędziego $\mathrm{w}$ uwierzytelnionej przez notariusza kopii ${ }^{100}$. W postanowieniu określa się termin, który przysługuje stronom na udzielenie odpowiedzi. Obrońca węzła ma prawo zabrać głos jako ostatni ${ }^{101}$, składając swoją replikę w kancelarii sądu.

Art. $244 \$ 2 \mathrm{DC}^{102}$ dopuszcza możliwość ustnej dyskusji sprawy. W tym przypadku podczas dyskusji powinien być obecny notariusz, aby zaprotokołować, w razie potrzeby, treść dyskusji i wnioski. Nadmienić trzeba, że w Sądzie Diecezjalnym w Tarnowie przepis ten praktycznie nie jest stosowany.

\section{Procedura wyrokowania i inne sposoby zakończenia procesu}

Sesja wyrokowa odbywa się według norm kan. 1609 крк. Kolegium sędziowskie podejmuje decyzję, a notariusz, według praktyki sądu tarnowskiego, zawiadamia strony o części rozstrzygającej i o wysokości kosztów końcowych. Sporządzony przez sędziego wyrok jest niezwłocznie ogłaszany przez notariusza ${ }^{103}$. Ogłoszenie odbywa się przez przekazanie

${ }^{98}$ DC art. 240; por. KPK kan. 1601.

99 A. Dzięga, Sprawy wpadkowe, publikacja akt, dyskusja sprawy, [w:] Proces małżeński według Instrukcji „Dignitas Connubii”...., dz. cyt., s. 123.

${ }^{100}$ DC art. $242 \$ 1$; por. KPK kan. $1603 \$ 1$.

${ }^{101}$ DC art. 243; por. KPK kan. $1063 \$ 3$.

${ }^{102}$ Por. KPK kan. 1605.

${ }^{103}$ DC art. 257; por. KPK kan. 1614. 
stronie kopii wyroku, uwierzytelnionej przez notariusza, wraz z dekretem ogłoszenia wyroku. Najczęściej przesyłana jest pocztą poleconą, choć zdarza się także, że strona odbiera kopię wyroku w sekretariacie sądu osobiście lub przez pełnomocnika ${ }^{104}$. Kopię wyroku otrzymuje także obrońca węzła małżeńskiego ${ }^{105}$. Zaznaczyć trzeba, że podpis notariusza na wyroku jest wymieniany jako jeden $z$ koniecznych elementów ${ }^{106}$.

Nie każdy proces kończy się wyrokiem. Niejednokrotnie wydarzają się sytuacje powodujące zakończenie procesu w inny sposób. Tak dzieje się, gdy jedna ze stron umiera $\mathrm{w}$ trakcie procesu, gdy strona powodowa przestaje interesować się procesem lub rezygnuje z prowadzenia procesu, przy aprobacie lub obojętności strony pozwanej ${ }^{107}$. W każdym z tych przypadków notariusz, na polecenie sędziego, sporządza dekret zawieszenia bądź deklarację umorzenia instancji, a akta sprawy składa $\mathrm{w}$ archiwum sądu ${ }^{108}$.

\section{Procedura podważania wyroku}

Strony i obrońca węzła mogą w przewidzianym terminie złożyć w kancelarii sądu swoją apelację. Apelacja zwykle jest sporządzana na piśmie i w takiej formie składana w sekretariacie sądu. Kodeks przewiduje także możliwość złożenia ustnej apelacji, którą notariusz ma zredagować na piśmie ${ }^{109}$. Wyrok wraz z apelacjami, jeśli takie są, i pozostałymi aktami sądowymi, notariusz przesyła do trybunału apelacyjnego. Powinien to zrobić w ciągu 20 dni od ogłoszenia wyroku ${ }^{110}$. Dla sądu tarnowskiego trybunałem apelacyjnym jest Sąd Metropolitalny w Krakowie. Do niego trafiają wszystkie sprawy zakończone w Tarnowie wyrokiem pozytywnym i te, w których wpłynęła apelacja od wyroku negatywnego, o ile nie była skierowana bezpośrednio do Roty Rzymskiej. Regułą jest apelacja do Trybunału II Instancji w Krakowie. Zaledwie kilka apelacji w omawianym okresie skierowanych było do Roty Rzymskiej.

\footnotetext{
${ }^{104}$ DC art. 258 \$1; por. KPK kan. 1615.

${ }^{105}$ DC art. $258 \$ 2$.

${ }^{106}$ DC art. $253 \$ 1$; por. KPK kan. $1612 \$ 1$.

${ }^{107}$ DC art. 143-152; por. kan. 1518-1525 KРК.

${ }^{108}$ DC art. $61 \$ 2$.

${ }^{109}$ DC art. 281; KPK kan. 1630.

${ }^{110}$ DC art. 264; por. KPK kan. $1682 \$ 1$.
} 


\section{Procedura wykonania wyroku i przechowanie akt}

Po zatwierdzeniu przez Trybunał II Instancji (lub Rotę Rzymską) wyrok staje się wykonalny ${ }^{111}$. Art. 300 DC nakłada na wikariusza sądowego obowiązek natychmiastowego powiadomienia o wykonalnym wyroku ordynariusza miejsca zawarcia małżeństwa. Ten ma zatroszczyć się o odnotowanie orzeczenia nieważności małżeństwa wraz z ewentualnymi zakazami w księgach małżeństw i ochrzczonych ${ }^{112}$.

$\mathrm{W}$ praktyce zadanie powiadamiania o wyroku wykonalnym wypełniają sądy, a ściślej mówiąc notariusz, na polecenie wikariusza sądowego. Praktyką sądu tarnowskiego jest bezpośrednie zwracanie się o dokonanie adnotacji do parafii chrztu stron, bez obciążania tym obowiązkiem proboszcza parafii zawarcia małżeństwa. Stąd dbałość o umieszczenie w aktach sprawy informacji o dacie i parafii chrztu obu stron (najlepiej świadectw chrztu). Trudności pojawiają się, gdy prośba o dokonanie adnotacji wpływa $z$ innego sądu. Często w takiej prośbie brak istotnych danych, np. imion stron, dat urodzenia. Trzeba wtedy podjąć szereg działań i kontaktować się z kilku proboszczami, aby ustalić miejsce przechowywania konkretnej księgi metrykalnej.

Po uzyskaniu od proboszczów potwierdzenia dokonania adnotacji w księdze zaślubionych i w księgach ochrzczonych, akta przekazywane są do archiwum sądu. Zgodnie z art. $61 \$ 2 \mathrm{DC}$ pieczę nad tym archiwum sprawuje kierownik kancelarii sądu (notariusz). W sądzie tarnowskim wielkość archiwum sądu ograniczona jest dostępną przestrzenią. Do 2002 roku obejmowało ono wielką liczbę woluminów, jednak po przeniesieniu sądu do innego budynku zostało znacznie ograniczone. W latach 2002-2013 w pomieszczeniach sądu przechowywane były akta spraw zakończonych w przeciągu 5 poprzedzających lat, obecnie zawiera akta z ostatnich 7 lat, a docelowo będzie to 10 lat. Starsze akta przekazywane są sukcesywnie do Archiwum Diecezjalnego, gdzie w wydzielonym sektorze przechowywane będą aż do naturalnego zniszczenia.

Akta procesu są tajne. Mogą być udostępnione, za zgodą wikariusza sądowego, np. do postępowania o wyrażenie zgody na ponowne małżeństwo strony.

\footnotetext{
${ }^{111}$ DC art. $301 \$ 1$; por. KPK kan. $1684 \$ 1$.

${ }^{112}$ Por. KPK kan. 1685.
} 


\section{Tworzenie akt}

W ostatniej części opracowania wypada poświęcić trochę uwagi samemu procesowi tworzenia akt. Ogólna zasada stanowi, że akta sprawy mają być sporządzone na piśmie, a poszczególne karty akt należy numerować i uwierzytelnićn ${ }^{113}$.

Zgodnie z wieloletnią praktyką Sądu Diecezjalnego w Tarnowie wszelkie pisma procesowe sporządzane są na papierze formatu A4, pisane na jednej stronie kartki, z zachowaniem marginesu $(\mathrm{ok} .3 \mathrm{~cm}$ ) po lewej stronie, umożliwiającego zszycie akt. Niewłaściwy format papieru przestał być problemem, odkąd powszechne stało się redagowanie pism za pomocą komputerowego edytora tekstu. Pisma pisane ręcznie często były redagowane na formacie zeszytowym (A5) lub na formacie $\mathrm{A}_{3}$. Niejednokrotnie strony nie zachowywały marginesu lub zostawiały margines po prawej stronie. Obecnie najczęściej spotykanym błędem jest brak podpisu pod wydrukiem komputerowym, wymagający uzupełnienia.

Poszczególne karty akt gromadzone są w specjalnie przygotowanych okładkach i układane według dat wpłynięcia. Po przesłuchaniach akta uzupełniane są o opinie księży proboszczów o stronach i świadkach. Jest to praktyczne rozwiązanie, ponieważ sąd prosi o zaopiniowanie tylko tych osób, które złożyły zeznania. Wyjątkiem od tej zasady jest żądanie zawsze opinii o stronie pozwanej ${ }^{114}$.

Przed przekazaniem do biegłego notariusz porządkuje akta. Zasadą jest umieszczanie kolejno zeznań: strony powodowej, strony pozwanej (lub wezwań i dekretu nieobecności), świadków, a na koniec dołącza się wezwania świadków, którzy nie przybyli do zeznań. Po ułożeniu akt notariusz numeruje każdą stronę. Numerowanie stron zabezpiecza akta przed pomieszaniem kart w trakcie sporządzania opinii, a jednocześnie daje biegłemu możliwość powołania się w opinii na numer konkretnej strony akt.

Jeśli zachodzi potrzeba sporządzenia opinii biegłego lub ogłoszenia akt w sądzie innej diecezji, notariusz nie przesyła oryginału, lecz sporządza i uwierzytelnia kopię akt. Dokonuje tego, przybijając pieczęć, umieszczając datę i podpis.

\footnotetext{
${ }^{113}$ DC art. 88; KPK kan. 1472.

${ }^{114}$ DC art. 201; KPK kan. 1572.
} 
Kolejno umieszczane w aktach i numerowane są: opinia biegłego, dekret ogłoszenia akt, postanowienie o zamknięciu postępowania dowodowego, postanowienie o ogłoszeniu uwag oraz odpowiedzi stron i adwokatów. Tak uporządkowane akta stanowią materiał dla sędziów do przygotowania wotum sędziowskiego.

Po wydaniu i sporządzeniu wyroku do akt dołączany jest oryginał wyroku i dekret ogłoszenia wyroku. Ponadto notariusz opatruje akta spisem treści i kartą tytułową, układa w tekturowej teczce i przekazuje do oprawy wiarygodnej introligatorni. Oprawione akta uwierzytelnia, pieczętując i parafując każdą stronę. Dopiero tak przygotowane akta przesyłane są (w oryginale) do Trybunału II Instancji listem poleconym. Zaznaczyć trzeba, że dotychczas nie zdarzyło się, by przesyłane akta zaginęly, mimo że wracają również pocztą i również w oryginale. Kopię akt i ich wersję elektroniczną sporządza się, jeśli zachodzi konieczność przesłania sprawy do Roty Rzymskiej. Dopiero od jakichś 2-3 lat akta do Roty Rzymskiej przesyłane są za pośrednictwem Trybunału II Instancji. Poprzednio zasadą było przesyłanie własnych akt przez każdy trybunał. Akta, po dokonaniu adnotacji o wydanym wyroku w księgach metrykalnych, przekazywane są do archiwum sądu i tam przechowywane.

Lata 1983-2015 w związku ze znacznymi zmianami w prawie kanonicznym były okresem szczególnych wyzwań dla pracowników sądów. W Sądzie Diecezjalnym w Tarnowie był to czas analizowania nowego prawa i wypracowywania niezbędnych schematów postępowania, które złożyły się na określoną praktykę. Dzięki podejściu pełnemu szacunku do dokonań poprzedników praktyka była i jest rozwijana i ubogacana przez kolejnych pracowników sądu, w tym notariuszy. Dzięki temu było możliwe dostosowanie bez większych trudności działalności notariatu do kolejnych zmian w przepisach. Również bez komplikacji praca notariatu mogła być rozdzielona między dwie równocześnie i równoprawnie działające osoby.

We wskazanym okresie strony zyskały większe uprawnienia w procesie, a także większą świadomość swoich uprawnień dzięki rozpropagowaniu ich w mediach i różnych publikacjach. O ile kilkanaście lat temu petenci często zdawali się na wiedzę i sumienie sędziów, akceptując brak własnej wiedzy, o tyle dzisiaj chcą sami podejmować decyzje w procesie i starają się w miarę możliwości uzyskać jak najpełniejszą wiedzę. Często proszą o wyjaśnienie nieznanych sobie kwestii, co stanowi bezlitosną weryfikację 
dla kompetencji, a często też dla cierpliwości notariuszy. Z pewnością pozytywnym zjawiskiem jest, że coraz więcej osób chce uporządkować sobie życie. Niestety daje się też zauważyć swego rodzaju roszczeniowość wobec sądu przy braku zrozumienia, czym w rzeczywistości jest proces o nieważność małżeństwa. Oczekiwanie szybkiego zakończenia postępowania, często bez podania świadków i innych dowodów, wskazuje na opaczne pojmowanie procesu przed sądem diecezjalnym jako "rozwodu”. Do pracowników sądu, szczególnie do notariuszy, do których w pierwszej kolejności trafiają strony, należy uświadomienie im różnic między tymi dwoma postępowaniami.

Niewątpliwie notariusz pełni istotną rolę w sądzie, i to na wielu płaszczyznach. Jest to rola służebna względem sędziego, niemniej wykonywana ze znajomością przepisów prawa i z zaangażowaniem w istotny sposób wpływa na sprawny przebieg procesu. Dlatego od notariusza wymaga się stałego podnoszenia kwalifikacji, na równi z innymi pracownikami sądu, oraz stałej troski o rozwijanie i dostosowywanie praktyki sądowej do zmieniającego się prawa. Dziś notariusze stają przed nowym wyzwaniem, jakim jest zaaplikowanie do praktyki Sądu Diecezjalnego w Tarnowie przepisów wspomnianego już motu proprio Mitis Iudex Dominus Iesus. Wierzę, że i tym razem podjęte zadanie zostanie wykonane $\mathrm{z}$ sukcesem. 